\title{
FILTRATION OF PARAMETERS OF THE UAV MOVEMENT AT COMPLEX USE OF DATA SENSOR NETWORKS, OBTAINED BASED ON THE TDOA AND RSS METHODS
}

\author{
Tovkach I.O., Zhuk S.Ya. \\ The Institute of Telecommunication Systems \\ National Technical University of Ukraine "Igor Sikorsky Kyiv Politechnic Institute”, Kyiv, Ukraine
}

Background. At the present time the development of technologies for construction of unmanned aerial vehicles (UAVs) are used for the solution of a wide range of tasks, such as: emergency rescue operations, autonomous observation and monitoring of industrial processes and environment (fauna monitoring), etc. On the other hand, their availability and massive use for a wide range of problems has led to the emergence of a new class of threats: application in terrorist purposes, photographing of secret objects, receiving unauthorized access to information in WLAN networks, invasion on the forbidden territory, etc. This leads to the need to develop security systems that solve the problem of detection, positioning and movement parameters of the UAV.

Objective. Synthesize algorithm the filtration of parameters of the UAV movement at complex use of data, obtained based on the TDOA and RSS methods.

Methods. Synthesis of algorithm the filtration of parameters of the UAV movement at complex use of data, obtained based on the TDOA and RSS methods, it is executed on the basis of the mathematical device of the extended Kalman filter. Efficiency analysis of a developed algorithm is carried out by means of statistical modeling. For descriptive reasons of the algorithm works the test trajectory of the UAV movement has been created. Error RMS of measurement when using TDOA and RSS methods are $\sigma_{\Delta}=2.4 \mathrm{~m}$ and $\sigma_{P}=1 \mathrm{~dB}$, respectively. Rate of information receipt $\mathrm{T}=1 \mathrm{~s}$. Tests were carried out for hundred realization.

Results. As appears from results of modeling, complex use of data allows reducing RMS errors of the position estimation of the UAV more, than by 3 times, in comparison with independent processing on the basis of the data obtained by the TDOA and RSS methods.

Conclusions. The algorithm filtration of parameters of the UAV movement synthesized on the basis of a mathematical apparatus of the expanded Kalman filter is recurrent and implements a sequential procedure for combining data obtained on the basis of the TDOA and RSS methods. The developed algorithm takes into account the dispersion of power measurement errors, received signals by sensors of the sensor network and determines the estimate of the unknown error of measuring the arrival time signal of the reference sensor.

Keywords: UAV; TDOA; RSS; the expanded Kalman filter; wireless sensor network; parameters of movement.

\section{Introduction}

At the present time the development of technologies for construction of unmanned aerial vehicles (UAVs) are used for the solution of a wide range of tasks, such as: emergency rescue operations, autonomous observation and monitoring of industrial processes and environment (fauna monitoring), etc. On the other hand, their availability and massive use for a wide range of problems has led to the emergence of a new class of threats [1-3]: application in terrorist purposes, photographing of secret objects, receiving unauthorized access to information in WLAN networks, invasion on the forbidden territory, etc. This leads to the need to develop security systems that solve the problem of detection, positioning and movement parameters of the UAV.
When an UAVs emits, its location can be determined by wireless sensor networks (WSN) [4,5] with use of methods of a passive location. In this case the time difference of arrival method (TDOA) is generally used, in which the differences of times of reception of signals received by various sensors and the reference sensor WSN are used. Also the received-signal strength (RSS) [8] method is used, in which the measured values of power of the accepted signal are used. These methods have an essential advantage in simplicity of implementation and finds broad practical application $[9,10]$. To improve the accuracy of estimation of parameters of the UAV movement can be achieved by complex processing of data obtained based on the TDOA and RSS methods. 


\section{Problem definition}

The movement UAV in rectangular system of coordinates can be described by a stochastic dynamic system in the form [11]:

$$
u(k)=F u(k-1)+G \omega(k),
$$

where $u(k)$ - the state vector including parameters of the UAV movement for axes of rectangular system of coordinates; $F, G$ - the matrixes describing of movement; $\omega(k)$ - the uncorrelated sequence of Gaussian vectors with a single correlation matrix.

For definition of UAV location the wireless sensor network has to consist not less than of four sensors. When using TDOA method, differences of signals reception times between sensors $l=\overline{1, L}$ and the basic sensor with coordinates of $x^{0}=0, y^{0}=0$ are measured.

During propagation of a signal from the UAV to sensors of network, its coordinate don't change.

$$
\begin{aligned}
h_{\Delta}^{l}(u(k)) & =\sqrt{\left(x(k)-x^{l}\right)^{2}+\left(y(k)-y^{l}\right)^{2}}- \\
& -\sqrt{x^{2}(k)+y^{2}(k)}-v^{0}(k)
\end{aligned}
$$

$x(k), y(k)$ - coordinates of the UAV position; $x^{l}, y^{l}$ - coordinates of the $l$-th sensor position; $v^{0}(k)$ - the distances measurement error for the reference sensor with dispersion $d_{\Delta}^{0}$.

When using RSS method, dependence of the received signal power from the distance between the sensor and the UAV is taken into account. Broad application is found by the model of direct distribution of a signal which considers only its attenuation [8]. In this case observation equation that describes the process of measuring the coordinates of UAV by sensor network has the form

$$
p^{l}(k)=h_{p}^{l}(u(k))+v^{l}(k), l=\overline{1, L},
$$

where $p^{l}(k)$ - the measured $l$-th sensor signal power of the UAV in the $k$-th moment of time,

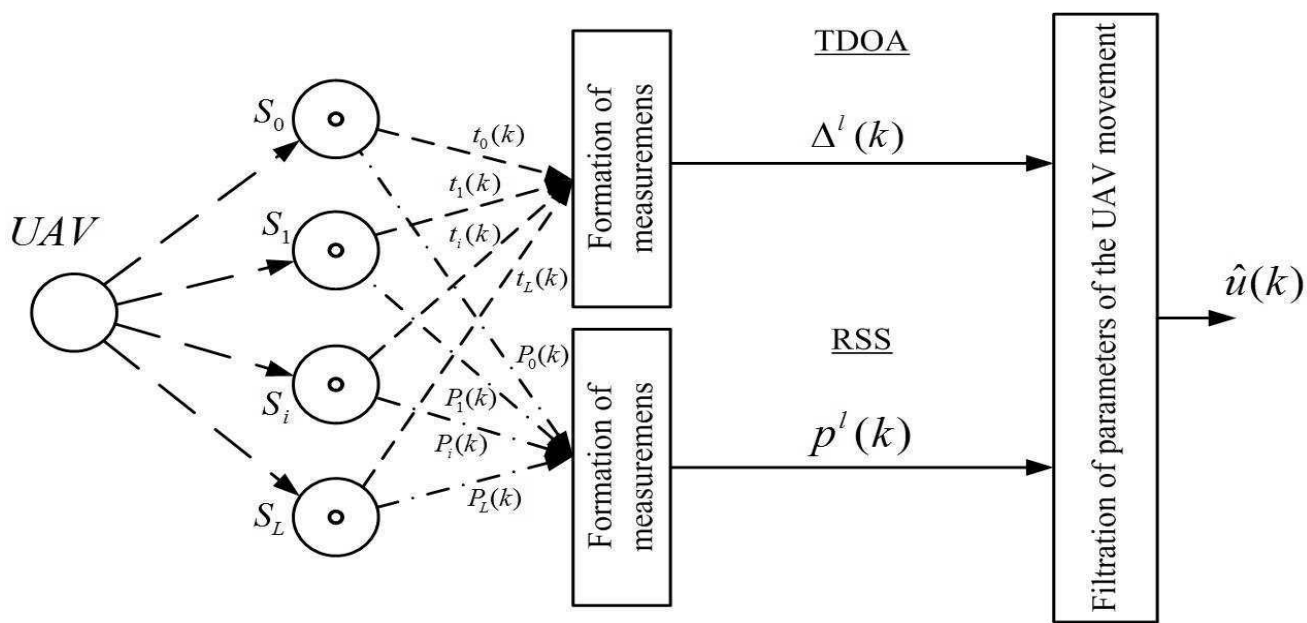

Fig. 1. Principle of determination location by TDOA and RSS methods.

Therefore, it is assumed that the measurements of the differences of distances between the sensors and the reference sensor are received in the $k$-th moment of time, as which the moment of a signal receipt to the reference sensor with coordinates of $x^{0}, y^{0}$ is used. In this case observation equation that describes the process of measuring the coordinates of UAV by sensor network has the form

$$
\Delta^{l}(k)=h_{\Delta}^{l}(u(k))+v^{l}(k), l=\overline{1, L}
$$

where $\Delta^{l}(k)$ - the measured difference of distances between the $l-$ th sensor and the reference sensor in the $k$-th moment of time, $l=\overline{1, L} ; v^{l}(k)$ - the measurement error of $l$-th sensor with dispersion $d_{\Delta}^{l} ; h_{\Delta}^{l}(u(k))$ - the nonlinear function, which is described by the formula $l=\overline{1, L} ; \quad v^{l}(k)$ - uncorrelated Gaussian measurement error of a received signal by the $l$-th sensor with zero mathematical expectation and dispersion $d_{p}^{l} ; h_{p}^{l}(u(k))$ - the nonlinear function, which is described by the formula $h_{p}^{l}(u(k))=p^{0}-10 \alpha \times$

$$
\times \lg \left(\frac{\sqrt{\left(x(k)-x^{l}\right)^{2}+\left(y(k)-y^{l}\right)^{2}}}{r^{0}}\right),
$$

where $p^{0}-$ the signal strength at a given distance $r^{0} ; \alpha-$ signal attenuation coefficient (close to 2 ); $x(k), y(k)$ - coordinates of the UAV position; $x^{l}, y^{l}-$ coordinates of the $l$-th sensor position. Measurement errors $v^{l}(k), l=\overline{1, L}$ are uncorrelated among themselves. 
To improve the accuracy of estimation of parameters of the UAV movement can be achieved by complex processing of data obtained based on the TDOA and RSS methods - Fig. 1. Thus, the joint vector of measurements has the form $u_{c}^{l T}(k)=\left(\Delta^{l}(k), p^{l}(k)\right)$.

On the basis of the model of the UAV movement (1) and the observation equations for sensor network $(2,4)$ it is necessary to synthesize algorithms the filtration of parameters of the UAV movement at complex use of data sensor networks, obtained based on the TDOA and RSS methods.

\section{Development}

Using the model $(1,2,4)$, the recurrent algorithm of estimation of the state vector $u(k)$ can be obtained based on extended Kalman filter [11, 12] and is described by the equations

$$
\begin{aligned}
& u^{*}(k)=F \hat{u}(k-1) \\
& P^{*}(k)=F \hat{P}(k-1) F^{T}+G G^{T} ; \\
& K_{\Delta}^{l}(k)=\hat{P}_{p}^{l-1}(k) \frac{\partial h_{\Delta}^{l T}\left(\hat{u}_{p}^{l-1}(k)\right)}{\partial u(k)} \times \\
& \times\left(\frac{\partial h_{\Delta}^{l}\left(\hat{u}_{p}^{l-1}(k)\right)}{\partial u(k)} \hat{P}_{p}^{l-1}(k) \frac{\partial h_{\Delta}^{l T}\left(\hat{u}_{p}^{l-1}(k)\right)}{\partial u(k)}+d_{\Delta}^{l}(k)\right)^{-1} ; \\
& \hat{u}_{\Delta}^{l}(k)=\hat{u}_{p}^{l-1}(k)+K_{\Delta}^{l}(k)\left(\Delta^{l}(k)-h_{\Delta}^{l}\left(\hat{u}_{p}^{l-1}(k)\right)\right) ; \\
& \hat{P}_{\Delta}^{l}(k)=\hat{P}_{p}^{l-1}(k)-K_{\Delta}^{l}(k) \frac{\partial h_{\Delta}^{l}\left(\hat{u}_{p}^{l-1}(k)\right)}{\partial u(k)} \hat{P}_{p}^{l-1}(k) ; \\
& K_{p}^{l}(k)=\hat{P}_{\Delta}^{l}(k) \frac{\partial h_{p}^{l T}\left(\hat{u}_{\Delta}^{l}(k)\right)}{\partial u(k)} \times \\
& \times\left(\frac{\partial h_{p}^{l}\left(\hat{u}_{\Delta}^{l}(k)\right)}{\partial u(k)} \hat{P}^{l-1}(k) \frac{\partial h_{p}^{l T}\left(\hat{u}_{\Delta}^{l}(k)\right)}{\partial u(k)}+d_{p}^{l}(k)\right)^{-1} ; \\
& \hat{u}_{p}^{l}(k)=\hat{u}_{\Delta}^{l}(k)+K_{p}^{l}(k)\left(p^{l}(k)-h_{p}^{l}\left(\hat{u}_{\Delta}^{l}(k)\right)\right) ; \\
& \hat{P}_{p}^{l}(k)=\hat{P}_{\Delta}^{l}(k)-K_{p}^{l}(k) \frac{\partial h_{p}^{l}\left(\hat{u}_{\Delta}^{l}(k)\right)}{\partial u(k)} \hat{P}_{\Delta}^{l}(k),
\end{aligned}
$$

where $\hat{u}_{\Delta}^{l}(k), \hat{P}_{\Delta}^{l}(k)$ - estimation of the state vector and the correlation matrix of estimation errors, refined by measurements $\Delta^{l}(k) ; \hat{u}_{p}^{l}(k), \hat{P}_{p}^{l}(k)$ - estimation of the state vector and the correlation ma- trix of estimation errors, refined by measurements $p^{l}(k)$. In this case the initial conditions for the procedure (14)...(19) at $l=1$ has the form $\hat{u}_{p}^{0}(k)=u^{*}(k), \hat{P}_{p}^{0}(k)=P^{*}(k)$.

The block diagram of filter is shown in Fig. 2.

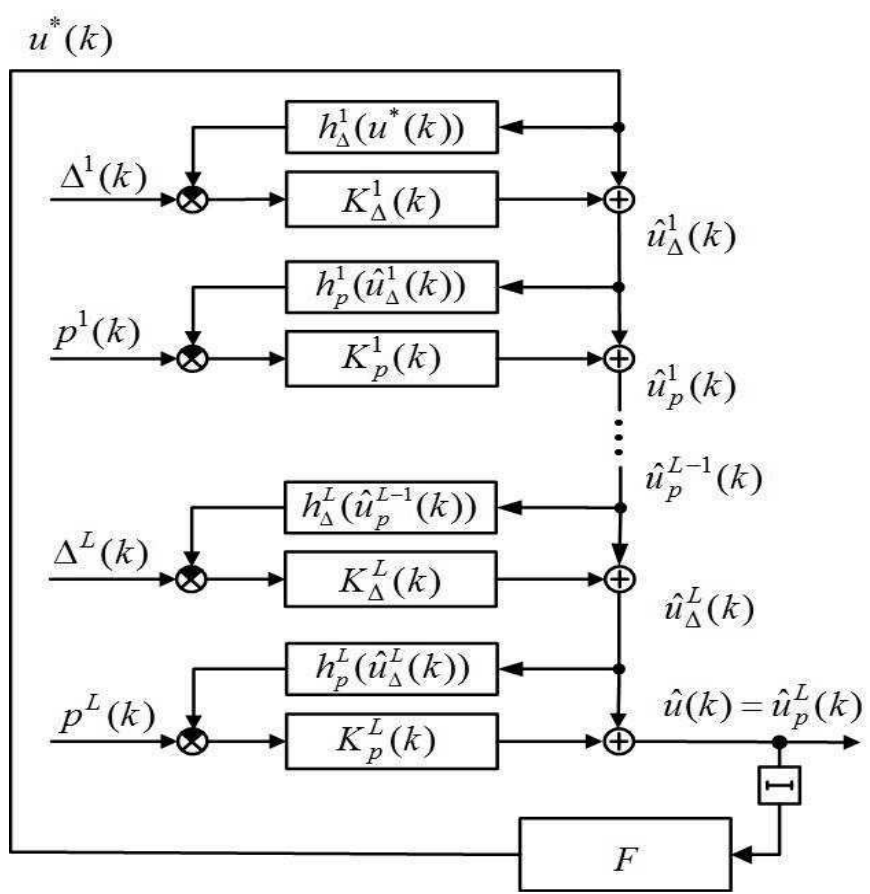

Fig. 2. The block diagram of the filter when at complex TDOA and RSS measurements

The estimation $\hat{u}(k)$ on each step of $k$ is calculated by means of serial processing of the input data arriving from measuring devices. The advantage of this method is an opportunity to organize processing with limited computing resources.

\section{Analysis of efficiency of an algorithm}

Efficiency analysis of a developed algorithm for estimating the parameters of the target movement (6)...(13) is carried out by means of statistical modeling. The structure of the sensor network shown in Fig. 3. It consists of nine sensors for definition of UAV location with coordinates: SO $(0 ; 0)$, S1 $(0 ; 100), \quad S 2 \quad(100 \sqrt{2} ; 100 \sqrt{2}), \quad \mathrm{S} 3 \quad(100 ; 0), \quad \mathrm{S} 4$ $(100 \sqrt{2} ;-100 \sqrt{2}), \quad$ S5 $\quad(0 ;-100), \quad$ S6 $(-100 \sqrt{2} ;-100 \sqrt{2}), \quad$ S7 $\quad(-100 ; 0), \quad$ S8 $(-100 \sqrt{2} ; 100 \sqrt{2})$.

For the description of the UAV movement, the model has used movement with the maneuver.

The state vector $u^{T}(k)=(x(k), \dot{x}(k), \ddot{x}(k), y(k)$, $\left.\dot{y}(k), \ddot{y}(k), v^{0}(k)\right)$ includes position coordinates, ve- 
locity and acceleration along the axes $X, Y$, and also measurement error of the reference sensor $v^{0}(k)$.

Switching $v^{0}(k)$ on in state vector $u(k)$, allows removing correlation of differences of distances between sensors in the TDOA method. The matrixes included in the motion model (1) have the form

$$
\begin{gathered}
F(k, k-1)=\left[\begin{array}{ccccccc}
1 & T & \frac{T^{2}}{2} & 0 & 0 & 0 & 0 \\
0 & 1 & T & 0 & 0 & 0 & 0 \\
0 & 0 & 1 & 0 & 0 & 0 & 0 \\
0 & 0 & 0 & 1 & T & \frac{T^{2}}{2} & 0 \\
0 & 0 & 0 & 0 & 1 & T & 0 \\
0 & 0 & 0 & 0 & 0 & 1 & 0 \\
0 & 0 & 0 & 0 & 0 & 0 & 1
\end{array}\right], \\
G^{T}(k)=\left[\begin{array}{cccccccc}
\frac{a T^{3}}{6} & \frac{a T^{2}}{2} & a T & 0 & 0 & 0 & 0 \\
0 & 0 & 0 & \frac{a T^{3}}{6} & \frac{a T^{2}}{2} & a T & 0
\end{array}\right]
\end{gathered}
$$

$a$ - RMS of random fluctuations of speed change of acceleration of the UAV. When modeling relied: $a=6 \mathrm{M} / \mathrm{c}^{3}$.

The partial derivatives $\frac{\partial h_{\Delta}^{l}\left(\hat{u}_{p}^{l-1}(k)\right)}{\partial u(k)}$ and $\frac{\partial h_{p}^{l}\left(\hat{u}_{\Delta}^{l-1}(k)\right)}{\partial u(k)}$, included in equation $(8,11)$, have the form

$$
\begin{aligned}
& \frac{\partial h_{\Delta}^{l}\left(\hat{u}_{p}^{l-1}(k)\right)}{\partial u(k)}=\left[\begin{array}{l}
\frac{\hat{x}(k-1)-x^{l}}{\sqrt{\left(\hat{x}(k-1)-x^{l}\right)^{2}+\left(\hat{y}(k-1)-y^{l}\right)^{2}}}- \\
\frac{\hat{x}(k-1)}{\sqrt{\hat{x}(k-1)^{2}+\hat{y}(k-1)^{2}}} ; 0 ; 0 ; \\
\frac{\hat{y}(k-1)-y^{l}}{\sqrt{\left(\hat{x}(k-1)-x^{l}\right)^{2}+\left(\hat{y}(k-1)-y^{l}\right)^{2}}}- \\
-\frac{\hat{y}(k-1)}{\sqrt{\hat{x}(k-1)^{2}+\hat{y}(k-1)^{2}}} ; 0 ; 0 ;-1
\end{array}\right], \\
& \frac{\partial h_{p}^{l}\left(\hat{u}_{\Delta}^{l}(k)\right)}{\partial u(k)}=\frac{-10 \cdot \alpha}{\ln (10)} \cdot\left[\begin{array}{l}
\frac{\hat{x}(k-1)-x^{l}}{\left(\hat{x}(k-1)-x^{l}\right)^{2}+\left(\hat{y}(k-1)-y^{l}\right)^{2}} ; \\
0 ; 0 ; \\
\frac{\hat{y}(k-1)-y^{l}}{\left(\hat{x}(k-1)-x^{l}\right)^{2}+\left(\hat{y}(k-1)-y^{l}\right)^{2}} \\
0 ; 0 ; 0
\end{array}\right] .
\end{aligned}
$$

For descriptive reasons of the algorithm works the test trajectory of the UAV movement (Fig. 3) has been created. The trajectory consists of five sections: first $1<\mathrm{k}<42$ - uniform motion, second $43<\mathrm{k}<45-$ maneuver, third $46<\mathrm{k}<84$ - uniform motion, fourth $85<\mathrm{k}<114$ - hanging, fifth $115<\mathrm{k}<130$ - uniform motion. Error RMS of measurement when using

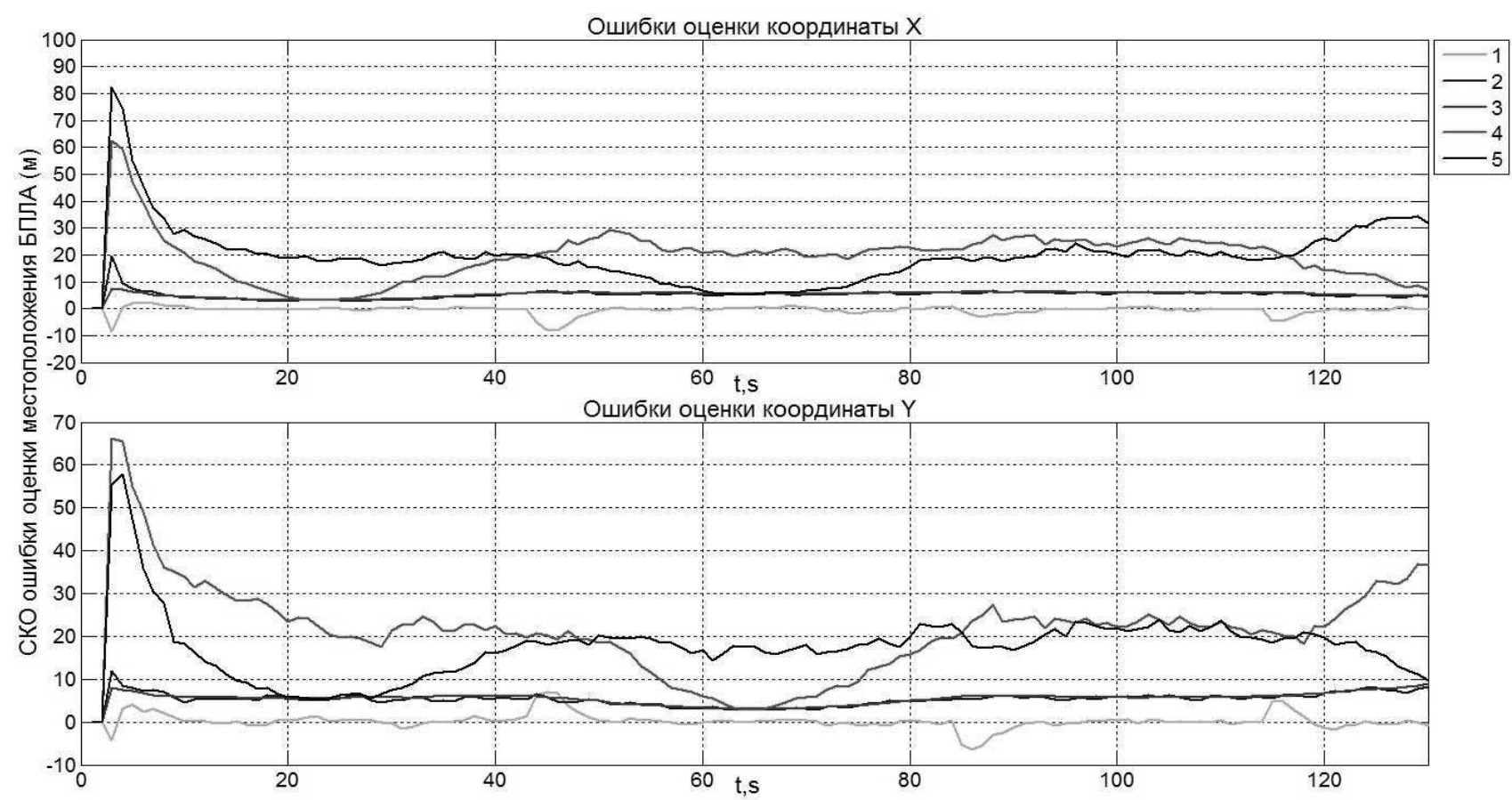

Fig. 4. RMS errors of the position estimation of the UAV 
TDOA and RSS methods are $\sigma_{\Delta}=2.4 \mathrm{~m}$ and $\sigma_{P}=1 \mathrm{~dB}$, respectively. Rate of information receipt $\mathrm{T}=1 \mathrm{~s}$. Tests were carried out for hundred realization. The initial conditions of the filtering algorithm $\hat{u}(0), \hat{P}(0)$ was formed using the Least Squares method on the current measurements at two initial clock cycles.

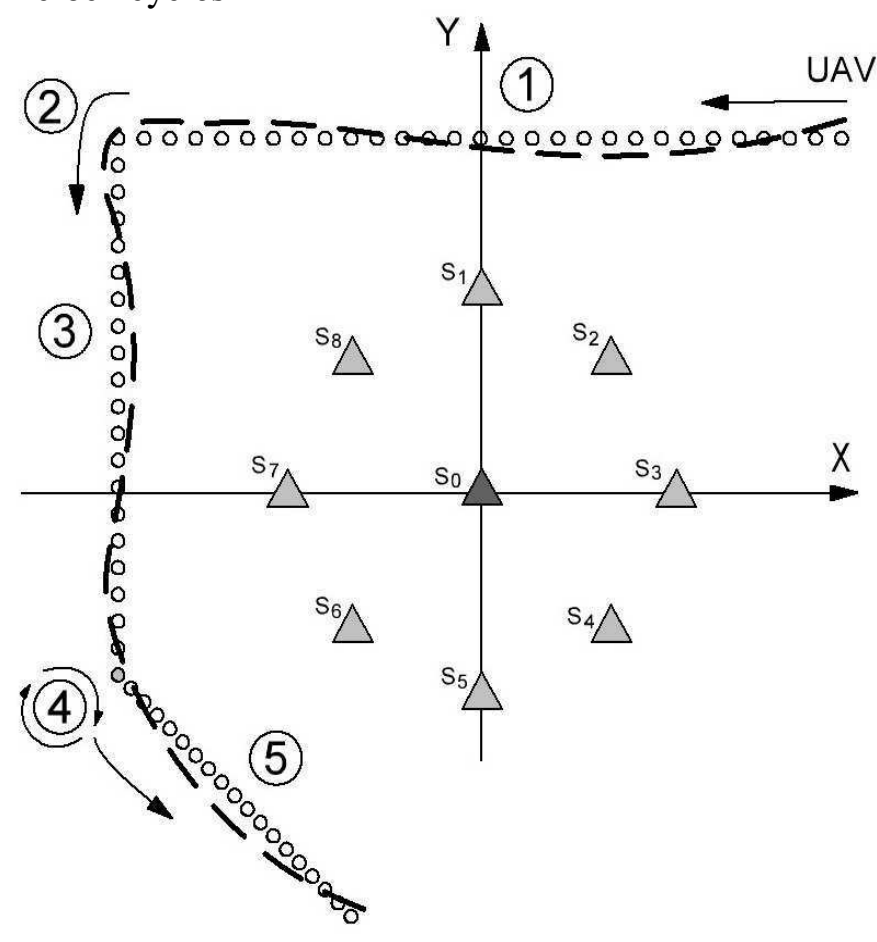

Fig. 3. The structure of the sensor network with 9 sensors and the trajectory of UAV movement.

Fig. 4 shows dependences of expected value (curve 1) and RMS (curve 2) errors of the position estimation of the UAV along coordinates of $\mathrm{X}, \mathrm{Y}$, and also RMS (curve 3) errors of assessment calculated by the developed filter obtained by Monte Carlo method. Also Fig. 4 shows dependences of RMS error of measurement of position of the UAV for Kalman's filtering in case of independent processing of the data obtained by TDOA method (curves 4) and by RSS method (curves 5). Complex use of data allows reducing RMS errors of the position estimation of the UAV more, than by 3 times.

\section{Conclusions}

The algorithm (6-13) filtration of parameters of the UAV movement synthesized on the basis of a mathematical apparatus of the expanded Kalman filter is recurrent and implements a sequential pro- cedure for combining data obtained on the basis of the TDOA and RSS methods. The developed algorithm takes into account the dispersion of power measurement errors, received signals by sensors of the sensor network and determines the estimate of the unknown error of measuring the arrival time signal of the reference sensor.

As appears from results of modeling, complex use of data allows reducing RMS errors of the position estimation of the UAV more, than by 3 times, in comparison with independent processing on the basis of the data obtained by the TDOA and RSS methods.

\section{References}

[1] Nonami K., Kendoul F., Suzuki S., Wang W., Nakazawa D. (2010) Autonomous Flying Robots Unmanned Aerial Vehicles and Micro Aerial Vehicles, N. Y., Springer, 329 p. DOI: 10.1007/978-4-431-53856-1

[2] Wallace, R. J., Loffi , J. M. (2015) Examining Unmanned Aerial System Thr eats \& Defenses: A Conceptual Analysis, International Journal of Aviation, Aeronauti- cs, and Aerospace, Volume 2, Issue 4, 33 p. DOI: 10.15394/ijaaa.2015.1084

[3] Zashchita ot dronov - nebesnyy rubezh vashey bezopasnosti [Electron resource] - Access mode to the resource: http://dronebouncer.com/ [4] Jose L. Rullan-Lara, Guillaume Sanahuja, Rogelio Lozano, Sergio Salaza, Ramon Garcia-Hernandez, Jose A. Ruz-Hernandez . "Indoor Localization of a Quadrotor Based on WSN: A Real-Time Application", International Journal of Advanced Robotic Systems, 2013, Vol. 10, 48:2013.

[5] Tarrno P., Bernardos A. M., Casar J. R. (2007) An RSS Localization Method Based on Parametric Channel Models, IEEE, International Conference on Sensor Technologies and Applications, pp. 265-270.

[6] Mao G., Fidan B., Anderson B. D.O. (2007) Wireless Sensor Network Localization Techniques, Journal Computer Networks: The International Journal of Computer and Telecommunications Networking archive, Volume 51, Issue 10, pp. 2529-2553.

[7] Alon Amar, Geert Leus. "A reference-free time difference of arrival source localization using a passive sensor array", IEEE Sensor Array and Multichannel Signal Processing Workshop, 2010, pp. 157-160.

[8] Tovkach, I. O., Zhuk, S. Ya. (2016) Recursive algorithm of the passive location in sensor networks based on measurement of the received signal strength, Visn. NTUU KPI, Ser. Radioteh. radioaparatobuduv., no. 66 , pp. 46-55.

[9] Masieroa A., Fissorea F., Guarnieria A., Pirottia F., Vettorea A. (2015) UAV positioning and collision avoi- dance based on RSS measurements, The International Archi- ves of the Photogrammetry, Remote Sensing and Spatial Information Sciences, Volume XL-1/W4, pp. 219225.

[10] "Sravneniye metodov opredeleniya geograficheskogo mestopolozheniya istochnika signala, osnovannykh na raznitse vo vremeni prikhoda i ugle prikhoda signala" Otchet MSE-R SM.2211-1 Zheneva, $2015 \mathrm{~g}$.

[11] Neuimin O. S., Zhuk S. Ya. Sequential detection of target trajectory using the decision statistics of pips. Radioelectronics and Communications Systems, 2014, vol. 57, no. 8, pp. 352-361. doi: 10.3103/S0735272714080032.

[12] Yevlanov P.A., Zhuk S.YA. (1990) Kompleksirovaniye izmeriteley s otkazami, Izvestiya vuzov USSR. Radioelektronika, Vol. 33, No. 3. pp. 15-21.

Received in final form on May 08, 2017 


\section{Товкач I.О., Жук С.Я.}

Фільтрація параметрів руху БПЛА при комплексному використанні даних сенсорної мережі, отриманих на основі методів TDOA і RSS

Проблематика. В даний час безпілотні літальні апарати (БПЛА), використовуються для вирішення широкого кола завдань, таких як: аварійно-рятувальні операції, автономне спостереження і моніторинг промислових процесів і навколишнього середовища (моніторинг тваринного світу) і ін. 3 іншого боку, їх доступність і масове використання привело до появи нового класу загроз: застосування в терористичних цілях, фотозйомка засекречених об'єктів, отримання несанкціонованого доступу до інформації в мережах WLAN, вторгнення на заборонену територію і ін. Це призводить необхідності розробки систем, які вирішують завдання виявлення, визначення місця розташування і параметрів руху БПЛА.

Мета досліджень. Синтезувати алгоритм фільтрації параметрів руху БПЛА при комплексній обробці даних, отриманих на основі методів TDOA і RSS.

Методика реалізації. Синтез алгоритму фільтрації параметрів руху БПЛА при комплексній обробці даних, отриманих на основі методів TDOA і RSS виконаний на основі математичного апарату розширеного фільтра Калмана. Аналіз отриманого алгоритму проведено за допомогою статистичного моделювання. Для опису руху БПЛА була сформована тестова траєкторія руху. СКО помилок вимірювань при використанні методів TDOA і RSS $\sigma_{\Delta}=2.4$ м і $\sigma_{P}=1$ дБ, відповідно. Темп надходження інформації $\mathrm{T}=1 \mathrm{c}$. Випробування проводилися по ста реалізаціях.

Результати досліджень. Результати дослідження показали, що комплексне використання даних дозволяє зменшити СКО помилки визначення місця розташування БПЛА більше, ніж в 3 рази в порівнянні з незалежною обробкою даних, отриманих методами TDOA i RSS.

Висновки. Синтезований на основі математичного апарату розширеного фільтра Калмана алгоритм фільтрації параметрів руху БПЛА є рекурентним і реалізує послідовну процедуру об'єднання даних, отриманих на основі методів TDOA i RSS. У розробленому алгоритмі враховуються дисперсії помилок вимірювання потужності прийнятих датчиками сенсорної мережі сигналів і визначається оцінка невідомої помилки вимірювання часу приходу сигналу опорного датчика.

Ключові слова: БПЛА; TDOA; RSS; фільтр Калмана; бездротова сенсорна мережа; параметри руху.

\section{Товкач И.О., Жук С.Я.}

Фильтрация параметров движения БПЛА при комплексном использовании данных сенсорной сети, полученных на основе методов TDOA и RSS

Проблематика. В настоящее время беспилотные летательные аппараты (БПЛА), используются для решения широкого круга задач, таких как: аварийно-спасательные операции, автономное наблюдение и мониторинг промышленных процессов и окружающей среды (мониторинг животного мира) и др. С другой стороны, их доступность и массовое использование привело к появлению нового класса угроз: применение в террористических целях, фотосъемка засекреченных объектов, получение несанкционированного доступа к информации в сетях WLAN, вторжение на запрещенную территорию и др. Это приводит к необходимости разработки систем, которые решают задачи обнаружения, определения местоположения и параметров движения БПЛА.

Цель исследований. Синтезировать алгоритм фильтрации параметров движения БПЛА при комплексной обработки данных, полученных на основе методов TDOA и RSS.

Методика реализации. Синтез алгоритма фильтрации параметров движения БПЛА при комплексной обработки данных, полученных на основе методов TDOA и RSS выполнен на основе математического апарата расширенного фильтра Калмана. Анализ полученого алгоритма проведен с помощью статистического моделирования. Для описания движения БПЛА была сформирована тестовая траектория движения. СКО ошибок измерений при использовании методов TDOA и RSS $\sigma_{\Delta}=2.4$ м и $\sigma_{P}=1$ дБ, соответственно. Темп поступления информации Т=1с. Испытания проводились по ста реализациях.

Результаты исследований. Результаты исследования показали, что комплексное использование данных позволяет уменьшить СКО ошибки определения местоположения БПЛА более, чем в 3 раза по сравнению с независимой обработкой данных, полученных методами TDOA и RSS.

Выводы. Синтезированный на основе математического аппарата расширенного фильтра Калмана алгоритм фильтрации параметров движения БПЛА является рекуррентным и реализует последовательную процедуру объединения данных, полученных на основе методов TDOA и RSS. В разработанном алгоритме учитываются дисперсии ошибок измерения мощности принимаемых датчиками сенсорной сети сигналов и определяется оценка неизвестной ошибки измерения времени прихода сигнала опорного датчика.

Ключевые слова: БПЛА; TDOA; RSS; фильтр Калмана; беспроводная сенсорная сеть; параметры движения. 